\title{
Stereo-Specific Transcript Regulation of the Polyamine Biosynthesis Genes by Enantiomers of Ornithine in Tobacco Cell Culture
}

\author{
Morteza Gholami ${ }^{1 *}$, Sedigheh Esmaeilzadeh Bahabadi ${ }^{2}$, Faezeh Ghanati ${ }^{3}$, Laleh Yousefzadeh Borojeni ${ }^{3}$ \\ ${ }^{1}$ Department of Chemistry, Faculty of Sciences, Golestan University, Gorgan, Iran \\ ${ }^{2}$ Department of Biology, Faculty of Basic Sciences, University of Zabol, Zabol, Iran \\ ${ }^{3}$ Department of Plant Biology, Faculty of Biological Sciences, Tarbiat Modares University, Tehran, Iran \\ "Corresponding author: Morteza Gholami, Department of Chemistry, Golestan University, Gorgan, Iran. Tel/Fax: +98 1732322904 , \\ E-mail: mo.gholami@gu.ac.ir
}

Received: 16 Feb. 2017; $\quad$ Revised: 18 Oct. 2017; Accepted: 11 Mar. 2018; Published online: 15 May 2018

\begin{abstract}
Background: Ornithine (Orn) plays an essential role in the metabolism of plant cells through incorporation in polyamines biosynthesis, the urea cycle and nitrogen metabolism. Physiological response of the plant cells to its two enantiomers have not been widely investigated yet.

Objectives: This study aimed to evaluate effect of ornithine enantiomers on expression of certain polyamine (PAs) biosynthetic genes in tobacco cells.

Materials and Methods: Suspension-cultured tobacco cells were treated with different concentrations of L- and D- Orn for $24 \mathrm{~h}$. Cell viability was assayed by Evans Blue and hydrogen peroxide content. The changes of gene expression were analyzed by semi-quantitative RT-PCR.

Results: Exogenous D-Orn resulted in enhancement of expression of genes involved in Orn, arginine and S-adenosyl methionine metabolism. Additionally, exogenous D-Orn treatment resulted in sustained viability of cultured tobacco cells and normal levels of hydrogen peroxide were maintained. Supplied L-Orn increased the hydrogen peroxide level and lowered viability of cells. Treatment with L-Orn had a negative effect on the transcript levels for most analyzed PA-related genes. It was also illustrated that transcription of putrescine methyl transferase, key enzyme for nicotine production, was highly upregulated by L-Orn.

Conclusions: Based on the results, D-Orn was shown to have a stereo-selective function in regulation of the PAs-related genes.

Keywords: Arginine decarboxylase, D-amino acids, Nicotiana tabacum, Ornithine decarboxylase.
\end{abstract}

\section{Background}

Polyamines (PAs), such as putrescine (Put), spermidine (Spd), and spermine (Spm), are generally present in all organisms and have essential roles in certain physiological processes $(1,2)$. PAs are present in all parts of the plant cells and are mostly known for involvement in the regulation of genome activity, cell division and expansion, and plant growth. PAs have important antioxidant functions, growth regulatory and essential interactions with components of the cell wall (3-5). Because of PAs participation in cell division processes and regulation of genome transcription, they are widely studied in cancer of animal cells (6).
Generally, Put is synthesized from Orn decarboxylation via ornithine decarboxylase (ODC; EC 4.1.1.19), and is then further aminopropylated by $S$-adenosyl methionine, spermidine synthase (SPDS; EC 2.5.1.16) and spermine synthase (SPMS; EC 2.5.1.22) to form Spd and Spm, respectively (7). In plants, Put can also be produced by arginine decarboxylase (ADC; EC 4.1.1.17) action (1). Methylation of Put by putrescine methyl transferase (PMT) and $S$-adenosyl methionine forms methyl putrescine (mPut), which provides the pyrrolidine ring of nicotine (7). Orn decarboxylation is known to be the main step in the PAs production. Transcription and enzyme activity of ODC are shown to be dominantly

Copyright (C 2017 The Author(s); Published by National Institute of Genetic Engineering and Biotechnology. This is an open access article, distributed under the terms of the Creative Commons Attribution-NonCommercial 4.0 International License (http://creativecommons.org/licenses/ by-nc/4.0/) which permits others to copy and redistribute material just in noncommercial usages, provided the original work is properly cited. 
regulated in many processes of living cells (8-10). ODC is shown to be present in all living organisms and necessary for cell division, transcription process and growth under normal condition. ADC is considered for taking role under stress conditions for the biosynthesis of PAs (1).

L-Orn is a non-protein amino acid and has an essential role in PAs biosynthesis (11). It also has main roles in arginine (Arg) and urea production (12). In addition, Orn has important function in the production of proline (Pro), and nicotinic alkaloids (7).

The content of PAs in plants are associated with several physiological processes, such as $\mathrm{N}: \mathrm{C}$ ratio and stress responses. PAs catabolism/anabolism, transport and conjugation define the PAs hemostasis (13).

It was previously shown that the "uncommon enantiomer", D-Orn, can cause upregulation of free and conjugated PAs, as opposed to its enantiomer (14). In addition, D-Orn potently induces production of Spd and Spm. While D-Orn has no effect on nicotine levels, L-Orn enhances nicotine production in vivo (14). Results of that study were the first observations suggesting a Amino Acid (D-AA) may play a critical role in plant metabolism and development. Generally, plants produce D-AAs due to microbial infection and racemization of L-AAs. Once compared to animals, plants assume to lack the D-AAs metabolizing enzymes that lead to toxicity effects of certain D-AAs in plants $(15,16)$. Mostly, D-AAs are thought to be toxic or futile compounds for plant metabolism, growth and development (17). D-Serine and D-Alanine are of those D-AAs, which strongly inhibit plants growth at $3 \mathrm{mM}$ concentration (15).

It has long been accepted that only L-AAs can effectively enter biosynthetic pathways and be incorporated with secondary metabolites and proteins structures of cells. Although the functions of L-AAs on plant metabolism are well known, there are few reports on effects of D-AAs.

\section{Objectives}

The effects of L- and D-Orn on PAs biosynthetic related genes were evaluated. Following our previous report, here we planned to determine the role(s) of Orn enantiomers in suspension-culture of Nicotiana tabacum.

\section{Materials and Methods}

\subsection{Suspension Culture and Treatments}

Tobacco (Nicotiana tabacum) cells were cultivated in a modified MS medium (18). The 5-day-old cells were treated with $0,1,5,10 \mathrm{mM}$ of L- and D- Orn (SigmaAldrich) for $24 \mathrm{~h}$ according to $(19,20)$. Cells were harvested and frozen for further analysis. Evans Blue was used to assay the cells viability (18).

\subsection{Hydrogen Peroxide $\left(\mathrm{H}_{2} \mathrm{O}_{2}\right)$ Content Determination} $\mathrm{H}_{2} \mathrm{O}_{2}$ concentrations were assayed according to Velikova et al. (21). Briefly, $0.2 \mathrm{~g}$ fresh cells were crushed with trichloroacetic acid $(0.1 \% \mathrm{w} / \mathrm{v})$, followed by centrifugation at $12,000 \times \mathrm{g}$ for $10 \mathrm{~min}$. The supernatant $(0.5 \mathrm{~mL})$ was mixed with $1 \mathrm{~mL}$ of $1 \mathrm{M}$ potassium iodide and $0.5 \mathrm{~mL}$ of $10 \mathrm{mM}$ potassium phosphate buffer. Absorbance measurement was carried out at $390 \mathrm{~nm}$.

\subsection{RNA Extraction and Semi Quantitative Reverse Transcriptase-PCR Analysis}

Gene expression changes were measured by semiquantitative RT-PCR. Total RNA was isolated from

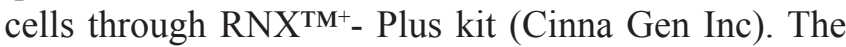
integrity and quantity of RNA was estimated using gel electrophoresis and spectrophotometer. Total RNA $(3 \mu \mathrm{g})$ was reverse-transcribed by First-Strand cDNA synthesis Kit (Fermentas, Canada). The primer sequences corresponding to the genes under study were shown in Table 1. Actin expression was used as an internal control. PCR reaction contained $0.5 \mathrm{U}$ Taq DNA polymerase, $0.3 \mu \mathrm{L}$ of cDNA, $200 \mu \mathrm{M}$ of deoxynucleoside triphosphates (dNTPs), $50 \mathrm{mM} \mathrm{KCl}$, $1.5 \mathrm{mM} \mathrm{MgCl}$ and $4 \mu \mathrm{M}$ of forward and reverse primers in a total volume of $20 \mu \mathrm{L}$. The PCR conditions were as follows: initial denaturation at $94{ }^{\circ} \mathrm{C}$ for $1 \mathrm{~min}$ and 30 cycles of $94{ }^{\circ} \mathrm{C}$ : $30 \mathrm{sec} ; 52$ to $58^{\circ} \mathrm{C}$ (depending on gene type): $25 \mathrm{sec}$; and extension for $10 \mathrm{~min}$ at 72 ${ }^{\circ} \mathrm{C}$. The products were electrophoresed in $1.2 \%(\mathrm{w} / \mathrm{v})$ agarose gels, stained with ethidium bromide under ultraviolet light. The band intensity was measured

Table 1. Sequences of primers used in this study.

\begin{tabular}{|c|c|}
\hline Genes & Sequences \\
\hline$A C T$ & $\begin{array}{l}\text { F- primer 5'-GCAGGGATCCACGAGACCACC-3' } \\
\text { R-primer 5'-CCCACCACTGAGCA CAATGTTCC-3' }\end{array}$ \\
\hline$O D C$ & $\begin{array}{l}\text { F- primer } 5^{\prime} \text {-TTCCAGAAGAAGTCGACCCGCTG-3' } \\
\text { R-primer } 5^{\prime} \text {-CA GCTCCGGTAACTGGTAATCCC-3' }\end{array}$ \\
\hline$A D C$ & $\begin{array}{l}\text { F- primer } 5^{\prime} \text {-ATCTGTCTTCTGGTGGCCTCC AATC-3' } \\
\text { R- primer } 5^{\prime} \text {-CCACCAATGAACTTATCAACCTTCC-3' }\end{array}$ \\
\hline$P A O$ & $\begin{array}{ll}\text { F- primer } & 5^{\prime} \text {-GACT CGGCAATTCAGAAACTCAG-3' } \\
\text { R-primer } & 5^{\prime} \text {-ACTCCTTCTCAGGTTCACAAGGC-3' }\end{array}$ \\
\hline$C A T$ & $\begin{array}{l}\text { F- primer } 5 \text { '-GTTTCTCACCTCACCTGTGCCG-3' } \\
\text { R-primer } 5 \text { 5'-CAGCGGCAATCGA AT CGTACAG-3' }\end{array}$ \\
\hline$S A M D C$ & $\begin{array}{l}\text { F- primer } 5^{\prime} \text { - TTGGTAGCAACATCAGCATGCA-3' } \\
\text { R-primer } 5^{\prime} \text {-TGACCCTGTTTACACTCTTGAG-3' }\end{array}$ \\
\hline
\end{tabular}



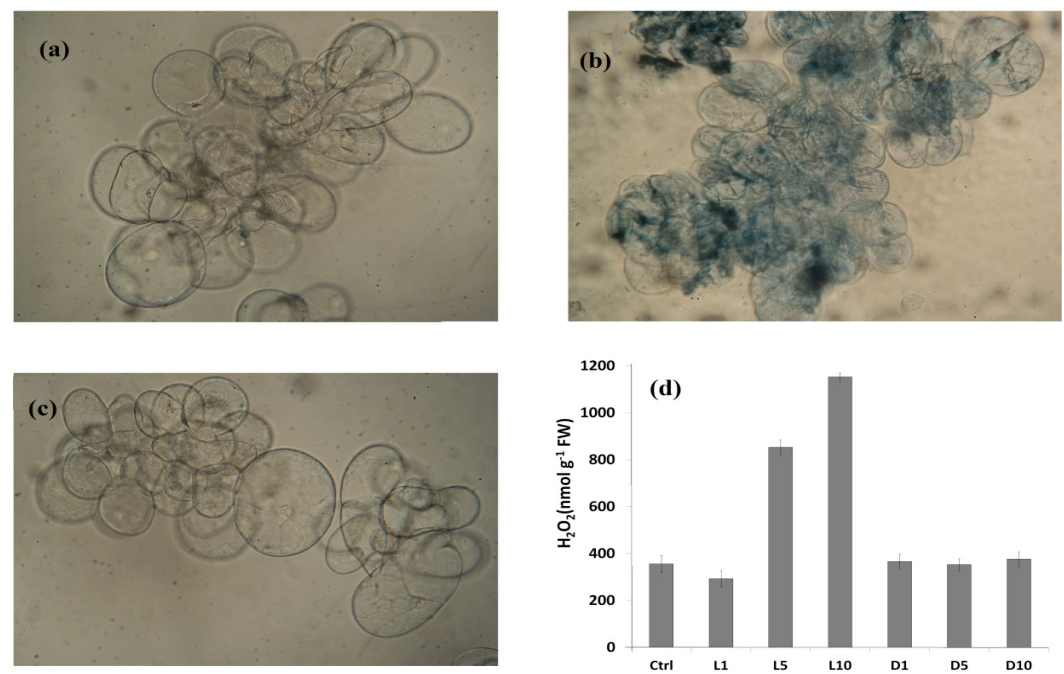

Figure 1. The viability and $\mathrm{H}_{2} \mathrm{O}_{2}$ levels of tobacco cells. a) control condition, b) L-Orn treated cells $(5 \mathrm{mM})$, c) D-Orn treated cells $(5 \mathrm{mM})$, d) $\mathrm{H}_{2} \mathrm{O}_{2}$ levels of cells after treatment with different concentrations of L- and D-Orn. Dead cells were stained blue due to loss of cell membrane integrity and insertion of Evans blue agent. Data represent average values from 3 separate experiments $\pm \mathrm{SD}$. by UV Documentation Luminescent Image Analysis software (England). The band quantity was determined with Image Guage software.

\section{Results}

\subsection{Effect of Orn on Cell Viability, Growth and $\mathrm{H}_{2} \mathrm{O}_{2}$ Content of Tobacco Cells}

No changes in cell viability were observed in D-Orn treated cells compared to the control (Figs. 1a and c). Conversely, treatments of cells with different concentrations of L-Orn inhibited cell viability (Fig. $1 \mathbf{b})$. Effect of $1 \mathrm{mM}$ concentration of L- and D-Orn on cell growth was evaluated. The results showed that cell growth was increased by L- and D-Orn (Table 2). Concurrent measurement of $\mathrm{H}_{2} \mathrm{O}_{2}$ levels showed that $\mathrm{H}_{2} \mathrm{O}_{2}$ concentration in the D-Orn treated cells is similar to the control condition, while L-Orn led to increasing $\mathrm{H}_{2} \mathrm{O}_{2}$ accumulation. $\mathrm{H}_{2} \mathrm{O}_{2}$ increment led to cell viability reduction (Fig. 1d). The key observation from D-Orn treated cells (up to $10 \mathrm{mM}$ ) was that these cells did not suffer from any damage. Moreover, they did not accumulate $\mathrm{H}_{2} \mathrm{O}_{2}$ or showed any lowered viability. Whereas $5 \mathrm{mM}$ L-Orn resulted in eleveated $\mathrm{H}_{2} \mathrm{O}_{2}$ that consequently lowered cell viability.

Table 2. Effect of D-Orn and L-Orn on growth of tobacco cells.

\begin{tabular}{cc}
\hline & Growth (g) \\
\hline Control & $11 \pm 0.5$ \\
D-Orn & $18 \pm 0.4$ \\
L-Orn & $16 \pm 0.3$ \\
\hline
\end{tabular}

4.2. Effect of Orn on PA Biosynthetic Gene Expression D-Orn showed a promotional effect on the expression of $O D C$ and $A D C$ genes, in a concentration dependent manner (Figs. 2 and 3). Conversely, 5 and $10 \mathrm{mM}$ L-Orn treatment did not result in considerable changes of $O D C$ expression (Fig. 3). In comparison with L-Orn, which highly decreased $A D C$ and $S A M D C$ transcript expressions, D-Orn enhanced $A D C$ and SAMDC transcript levels. Biosynthesis of nicotine from Put competes with the production of Spd in tobacco. Results showed that the PMT transcript, representing the key enzyme involved in mPut and nicotine biosynthesis, is highly expressed in L-Orn treated cells (Fig. 3).

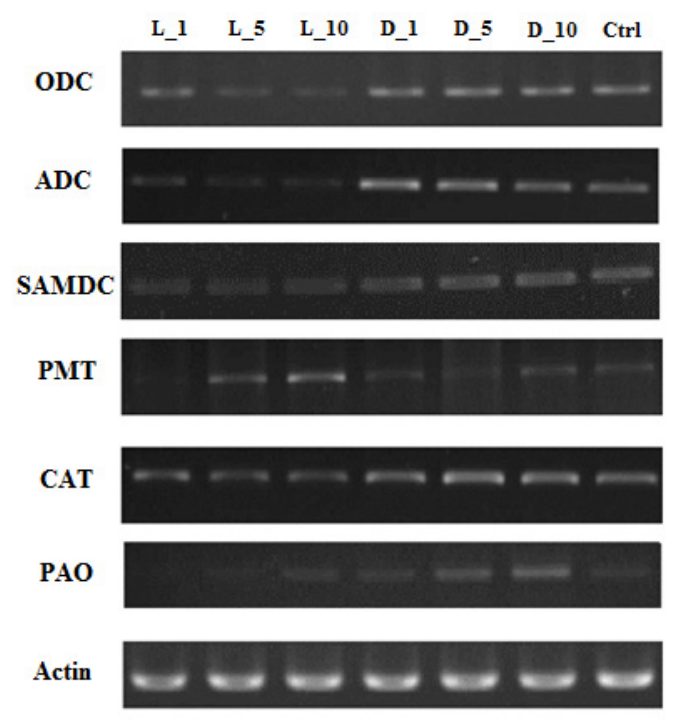

Figure 2. Expression patterns of $O D C, A D C, S A M D C, P M T$, $C A T, P A O$ and Actin in tobacco cells after L-Orn and D-Orn treatments with $0,1,5$ and $10 \mathrm{mM}$ concentrations. 

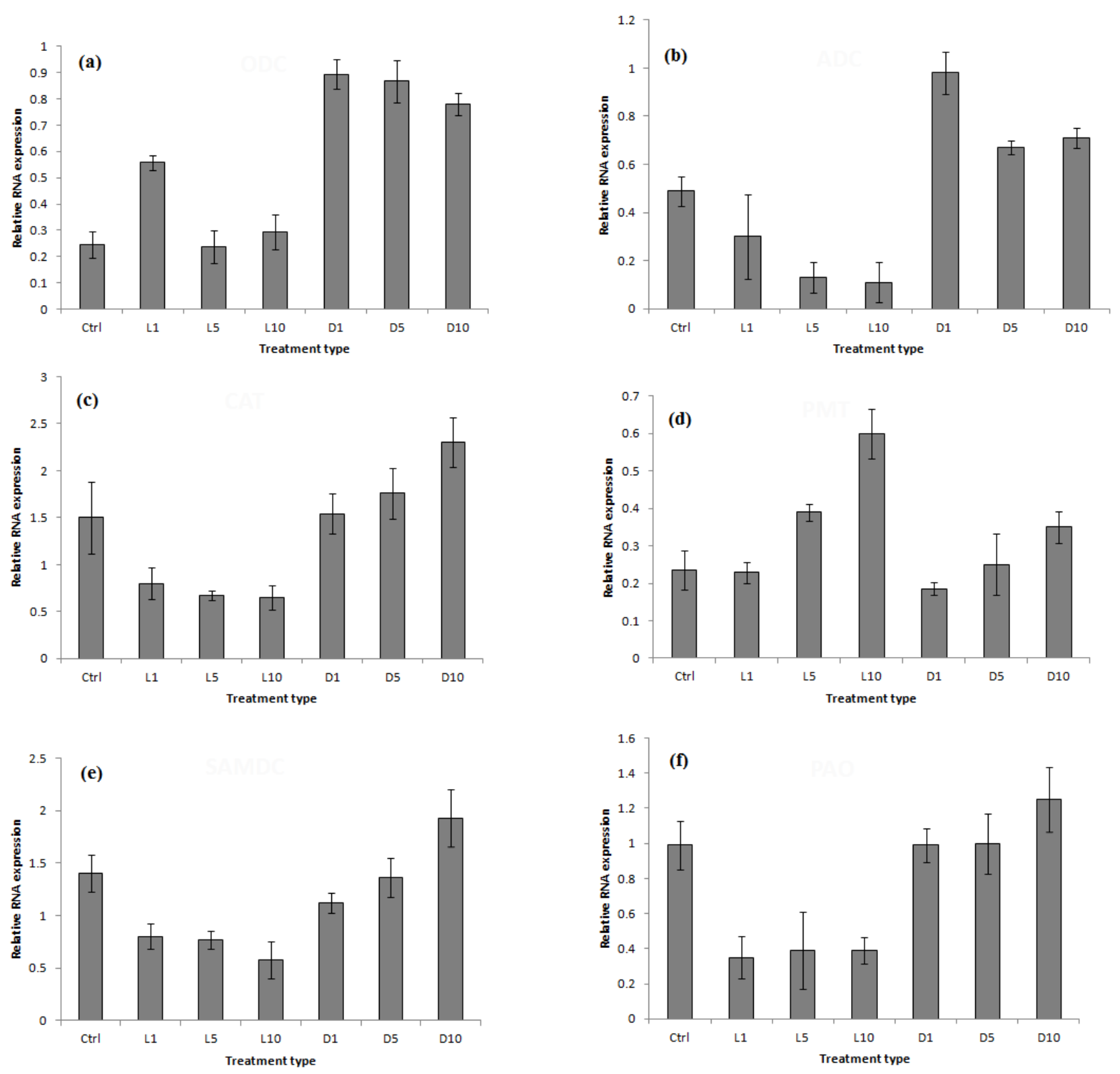

Figure 3. Expression level of the gene encoding for a) ODC, b) ADC, c) CAT, d) PMT, e) SAMDC, f) PAO in tobacco cell cultures after L-Orn and D-Orn treatments with $0,1,5$ and $10 \mathrm{mM}$ concentrations. Data represent average values from 3 separate experiments \pm SD.

\section{Discussion}

Our results showed that the application of D-Orn caused a sustained viability. Moreover, $\mathrm{H}_{2} \mathrm{O}_{2}$ content of cells were quite similar to the cells under normal condition. Therefore, it can be speculated that the observed upregulated levels of genes are not a sign of any stress induced by the D-Orn treatments. While certain D-AAs, e.g. D-Ala and D-Ser (at $3 \mathrm{mM}$ ) were shown to be very toxic and limit plant growth $(15,16)$, D-Orn showed no negative effect on cell suspension culture of tobacco, even at $10 \mathrm{mM}$. Based on our results, both
L-Orn and D-Orn might be involved in the regulation of respective pathways. Upregulation of all the necessary genes for Orn metabolism and PAs biosynthesis by D-Orn revealed its unique effects; the same effects have not been reported for L-Orn or any other D-AAs. While D-Orn emerged as a compound with stimulatory effects on transcript expressions of most associated genes, results for L-Orn implied a suppressive effect on their expression. In our previous paper, it was shown that L-Orn decreased Spd and Spn while increased nicotine. (14). This is in agreement with our result that 
L-Orn enhanced transcript of PMT as the key enzyme of nicotine biosynthesis. This observation shows that each enantiomer of Orn is different, if not opposing effects on the same pathways actually. Oxidation of PAs by diamine oxidase (DAO) and polyamine oxidases (PAO) produces $\mathrm{H}_{2} \mathrm{O}_{2}$. Apparently, these oxidizing enzymes act in opposite direction to catalase (CAT), as the main $\mathrm{H}_{2} \mathrm{O}_{2}$ scavenger. $P A O$ expression depicts a higher activity in the presence of D-Orn, which might be a reason to enhance the expression of CAT. The transcript level of $C A T$ was highly enhanced in the presence of D-Orn while the L-enantiomer showed no positive effect on CAT transcription level.

D-ornithine inhibits ODC in yeast (22). In addition, ODC activity in tobacco cells was shown to be inhibited by putrescine and other PAs (23). We have previously reported that the application of D-orn enhanced the levels of spermine and spermidine, but not putrescine (14). It seems that D-ornithine may increase the levels of spermidine and spermine through the activation of ADC and probably other genes including $S A M D C$, $S P D S$ and SPMS. The upregulated levels of $O D C$ and $A D C$ suggests that $\mathrm{D}$-Orn has a potential effect on the transcript of all the related genes to PAs metabolism. Higher enhancement of $P A O$ transcript, implies that PAs catabolism should be considered in addition to their production via ODC/ADC action. When examining different AAs for cell growth in suspension cultures, Behrend and Mateles (20) used a racemic mixture of Orn (at similar concentrations as in this study) and found that it acts as nitrogen source. An investigation into the effects of L-Orn on plant cell viability was reported in Aechmea fasciata. It was shown that L-Orn has inhibitory effects on growth of cultured pollen tubes (24). This data was in parallel to ours. Another notable study showed that L-Orn feeding to transgenic tobacco cell cultures (overexpressing an ODC) did not result in the expected accumulation of Put in cells, suggesting that Put production was limited partly by L-Orn availability (25). The results demonstrated that increasing capacity of cells to decarboxylate L-Orn increased the content of free or conjugated PAs.

$\mathrm{Qu}$ et al. showed that in comparison with the D-enantiomer, the L-enantiomer, is a more effective inhibitor of ODC (26). It has also been shown that ODCs extracted from different animal cells can be inhibited by both enantiomers. However, D-Orn is a very weak inhibitor of ODC (27), while L-Orn is a strong type. Ercal et al. showed that, treatments with most L-AAs are associated with a production of bulk of $\mathrm{H}_{2} \mathrm{O}_{2}$, which was not observed upon treatment with D-AAs. This is due to interconversion of AAs to each other through various cycles and catabolic reactions (28).

As expected, L-Orn can enter the amino acid cycles and pathways: resulting in increased $\mathrm{H}_{2} \mathrm{O}_{2}$ and other AAs while the D-enantiomer cannot. It can be safely argued that the constant level of $\mathrm{H}_{2} \mathrm{O}_{2}$ in D-Orn treated cells is a result of upregulation of CAT, which is the main scavenger of $\mathrm{H}_{2} \mathrm{O}_{2}$.

CAT and PAO, $\mathrm{H}_{2} \mathrm{O}_{2}$ producers via catabolism of PAs, are acting on opposite directions. Moreover, D-Orn is shown to have a stimulatory effect on the transcripts of both producing and recycling of PA enzymes. Results of our study suggest that a combination of accumulation of $\mathrm{H}_{2} \mathrm{O}_{2}$, driven from L-AAs conversions, and inhibition of gene transcripts determine the observed effects of L-Orn on tobacco cells. Current study indicates that stereospecific regulation of PAs biosynthesis might be a novel approach to enhance plant cells' metabolism, growth and development. To fully determine the role of D-Orn will demand further metabolic examination such as stable isotope labeling.

\section{Acknowledgements}

We are thankful to Department of Plant sciences, Faculty of Biological Sciences, Tarbiat Modares University, Tehran- Iran for PCR analyses.

\section{References}

1. Alcázar R, Altabella T, Marco F, et al. Polyamines: molecules with regulatory functions in plant abiotic stress tolerance. Planta. 2010;231:1237-1249. doi: 10.1007/s00425-010-1130-0

2. Roussos PA, Pontikis CA. Changes of free, soluble conjugated and bound polyamine titers of jojoba explants under sodium chloride salinity in vitro. J Plant Physiol. 2007;164:895-903. doi:10.1016/j.jplph. 2006.05.003

3. Yang H, Shi G, Wang H, Xu Q. Involvement of polyamines in adaptation of Potamogeton crispus L. to cadmium stress. Aquat Toxicol.2010;100:282-288. doi:10.1016/j.aquatox.2010.07.026

4. Mapelli S, Brambilla IM, Radyukina NL, Ivanov YV, Kartashov AV. Free and bound polyamine changes in different plants as a consequence of UV-B light irradiation. Gen Appl Plant Physiol. 2008;34:55-66.

5. Shevyakova NI, Rakitin VY, Stetsenko LA, Aronova EE, Kuznetsov VV. Oxidative stress and flVV. Oxidat of free and conjugated polyamines in the halophyte Mesembryanthemum crystallinum L. under $\mathrm{NaCl}$ salinity. Plant Growth Regul. 2006;50:69-78. doi: 10.1007/s10725-006-9127-1

6. Wallace HM, Fraser AV, Hughes A. A perspective of polyamine metabolism. Biochem J. 2003;376:1-14. doi: 10.1042/ bj20031327

7. Katoh A, Ohki H, Inai K, Hashimoto T. Molecular regulation of nicotine biosynthesis. Plant Biotech. 2005;22:389-392. doi: 10.5511/plantbiotechnology. 22.389

8. Kwak SH, Lee SH. The transcript level independent activation of ornithine decarboxylase in suspension-cultured BY2 cells entering the cell cycle. Plant Cell Physiol. 2002;43:1165-1170. doi: $10.1093 / \mathrm{pcp} / \mathrm{pcf} 132$

9. Yoo TH, Park CJ, Ham BK, Kim KJ, Paek KH. Ornithine 


\section{Gholami M et al.}

decarboxylase gene $(\mathrm{CaODC1})$ is specifically induced during TMV-mediated but salicylate-independent resistant response in hot Pepper. Plant Cell Physiol. 2004;45:1537-1542. doi: $10.1093 / \mathrm{pcp} / \mathrm{pch} 176$

10. Jang SJ, Cho HW, Park KY, Kim YB. Changes in cellular polyamine contents and activities of their biosynthetic enzymes at each phase of the cell cycle in BY-2 cells. J Plant Biol. 2006;49:153-159. doi: 10.1007/BF03031011

11. Gholami M, Boughton BA, Fakhari AR, Ghanati F, Mirzaei $\mathrm{HH}$, Yousefzaei L, et al. Metabolomic study reveals a selective accumulation of L-arginine in the D-ornithine treated tobacco cell suspension culture. Process Biochem. 2014;49(1)140-147. doi:10.1016/j.procbio.2013.09.010

12. Mohapatra S, Minocha R, Long S, Minocha SC. Transgenic manipulation of a single polyamine in poplar cells affects the accumulation of all amino acids. Amino Acids. 2010;38:11171129. doi: 10.1007/s00726-009-0322-Z

13. Moschou PN, Wu J, Cona A, Tavladoraki P, Angelini R, Roubelakis-Angelakis KA. The polyamines and their catabolic products are significant players in the turnover of nitrogenous molecules in plants. $J$ Exp Bot. 2012;63(14):5003-5015. doi: $10.1093 / \mathrm{jxb} / \mathrm{ers} 202$

14. Gholami M, Fakhari AR, Ghanati F. Selective regulation of nicotine and polyamines biosynthesis in tobacco cells by ornithine enantiomers. Chirality. 2013;25:22-27. doi: 10.1002/ chir.22107

15. Erikson O, Hertzberg M, Näsholm T. A conditional marker gene allowing both negative and positive selection in plant. Nat Biotechnol. 2004;22:455-458. doi:10.1038/nbt946

16. Gordes D, Kolukisaoglu U, Thurow K. Uptake and conversion of D-amino acids in Arabidopsis thaliana. Amino Acids. 2011;40:553-563. doi:10.1007/s00726-010-0674-4

17. Näsholm T, Kielland K, Ganeteg U. Uptake of organic nitrogen by plants. New Phytol. 2009;182:31-48. doi: 10.1111/j.14698137. 2008.02751.x

18. Ghanati F, Morita A, Yokota H. Effects of aluminum on the growth of tea plant and activation of antioxidant system. Plant Soil. 2005;276:133-141. doi: 10.1007/ s11104-005-3697-y

19. Hao YJ, Kitashiba H, Honda C, Nada K, Moriguchi T. Expression of arginine decarboxylase and ornithine decarboxylase genes in apple cells and stressed shoots. $J$ Ex Bot. 2005;56:1105-1115. doi: 10.1093/jxb/eri102

20. Behrend J, Mateles RI. Nitrogen metabolism in plant cell suspension cultures. Plant Physiol. 1975;56:584-589. doi: 10.1104/pp.56.5.584

21. Velikova V, Yordanov I, Edreva A. Oxidative stress and some antioxidant systems in acid rain-treated bean plants, protective role of exogenous polyamines. Plant Sci. 2000;151:59-66. doi:10.1016/S0168-9452(99)00197-1

22. Fogle EJ, Toney D. Analysis of catalytic determinants of diaminopimelate and ornithine decarboxylases using alternate substrates. Biochim Biophys Acta. 2011;1814(9):1113-1119. doi:10.1016/j.bbapap.2011.05.014

23. Heimer YM, Mizrahi Y. Characterization of ornithine decarboxylase of tobacco cells and tomato ovaries. Biochem J. 1982;201: 373-376. doi: 0306-3275/82/020373-04\$01.50/1

24. Vervaeke I, Stichelbout L, Londers E, Deroose R, Proft PD. Influence of arginine, ornithine, DFMO and polyamines on division of the generative nucleus in cultured pollen tubes of Aechmea fasciata (Bromeliaceae). Plant Cell Tiss Org. 2005;81:77-82. doi: 10.1007/s11240-004-2726-5

25. Mayer MJ, Michael AJ. Polyamine homeostasis in transgenic plants overexpressing ornithine decarboxylase includes ornithine limitation. $J$ Biochem. 2003;134:765-772. doi: $10.1093 / \mathrm{jb} / \mathrm{mvg} 205$

26. Ning QU, Ignatenko NA, Yamauchi, P, Stringer DE, Levenson, C, Shannon P, Perrin S, Gerner EW. Inhibition of human ornithine decarboxylase activity by enantiomers of difluoromethylornithine. Biochem J. 2003;375:465-470. doi: 10.1042/bj20030382

27. Bey P, Danzin C, Van Dorsselaer V, Mamont P, Jung M, Tardif C. Analogues of ornithine as inhibitors of ornithine decarboxylase. New deductions concerning the topography of the enzyme's active Site. J Med Chem. 1978;21:50-56.

28. Ercal N, Luo X, Matthews RH, Armstrong DW. In vitro study of the metabolic effects of amino acids. Chirality. 1996;8:24-29. doi: 10.1002/(SICI)152036X(1996)8:1<24:AIDHIR6>3.0.CO;2-G. 